\title{
THE USE OF 3D CITY MODELS FORM OBLIQUE IMAGES ON LAND ADMINISTRATION
}

\author{
S.BAKICI ${ }^{\mathrm{a}}$, B.ERKEK ${ }^{\mathrm{a}}$, E.AYYILDIZ ${ }^{\mathrm{b}}$, L.ÖZMÜŞ ${ }^{\mathrm{b}}$
}

${ }^{\mathrm{a}}$ General Directorate of Land Registry and Cadastre, Department of Mapping, Ankara, (sbakici,berkek)@ tkgm.gov.tr

${ }^{\mathrm{b}}$ General Directorate of Land Registry and Cadastre, Department of Mapping, Ankara,(ekremayyildiz03,lozmus) @ tkgm.gov.tr

KEY WORDS: Civil Law, Cadastre, 3D Cadastre, Real Estate Value Assessment, Oblique Photogrammetry

\begin{abstract}
:
The article 718 of the civil law saying "The ownership on property includes the air above and terrain layers below to an extent providing benefit. The structures, plants and sources are included in the content of this ownership reserving the legal restrictions" and the cadastre law no. 3402 envisage 3D Cadastre.

3D data is required in order to perform 3D cadastre. To meet this requirement, oblique photogrammetry arises as the main data acquisition method. The data obtained by this method is used as base in 3D Cadastre and Land Administration activities.

3D cadastre required in the context of land administration activities in Turkey demands high resolution aerial oblique images to be used in services such as real estate value assessment \& marketing in urban areas, urban planning, unlicensed construction monitoring \& city administration and making location data (national address data etc.) intelligent.
\end{abstract}

\section{INTRODUCTION}

\subsection{Land Administration}

Land is a spatial magnitude, where all living creatures shelter, hold on to life and carry on vital activities throughout the history. It is among the most valuable and indispensible sources for all livings on earth. Since land is an extremely crucial asset, its administration becomes an important issue as well. Land administration is the act of creating, recording and presenting information on ownership, value and use of land and its associated resources (UNECE, 1996). Land administration requires decision making and implementation the decisions about the land. Decisions can be taken either individually or by a group of people. Countries provide their existing lands to be managed with respect to requests, requirements and laws depending to the technological advancements. The key point is the establishment of land administration for sustainable development. The modern land administration depends on the land management paradigm (Williamson et al., 2010). In this approach, land administration functions including land tenure, land use, land value and land development are treated as inseparable parts.

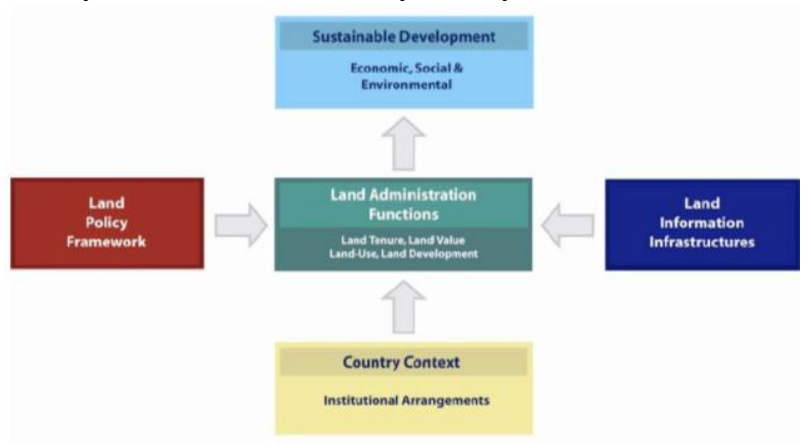

Figure 1. The land management paradigm (Enemark, 2004)

Sustainable development consists of economic, social and environmental components and the basis of the paradigm is the Institutional Arrangements depending on the country context. This basis can be defined by the three legs, which are Land Policies, Land Information Infrastructures and Land Administration Functions for sake of sustainable development. Land Policy can be defined as the purposes set by the governments to cope with land issues. These issues include economic development, social justice and equity and political stability. Land policies may differ from country to country regarding to social, economical and cultural aspects. Land Administration Functions is the operational component of the paradigm, which enables fair implementation of rights, restrictions and responsibilities about the land and its associated resources. As already mentioned, these functions are land tenure meaning securing and transferring rights in land, land use meaning planning and control of the land and properties, land value meaning valuation and taxation of land and properties and land development meaning implementing utilities, infrastructure and construction planning (Enemark, 2004). In order to serve these functions, solid Land Information Infrastructures are required, which include reliable cadastral and topographic data and gain access to thorough and updated information on artificial and natural environment. To sum up, the land management paradigm is required by modern land administration theory to make systems overcoming the land related right, restriction and responsibility issues for providing sustainable development (Williamson et al., 2010). 


\subsection{Cadastre}

In this scenario, cadastre comes up as one of the main components of a successful land administration. It locates at the core of a land administration system enabling spatial integrity and unique identification of land parcels. The statement of International Federation of Surveyors (FIG) on cadastre is given as follows: "A Cadastre is normally a parcel based, and up-to-date land information system containing a record of interests in land (e.g. rights, restrictions and responsibilities). It usually includes a geometric description of land parcels linked to other records describing the nature of the interests, the ownership or control of those interests, and often the value of the parcel and its improvements. It may be established for fiscal purposes (e.g. valuation and equitable taxation), legal purposes (conveyancing), to assist in the management of land and land use (e.g. for planning and other administrative purposes), and enables sustainable development and environmental protection" (FIG, 1996).

As indicated in the statement, land information is kept using parcels which use $2 \mathrm{D}$ boundaries to identify properties. To assure integrity and consistency, overlaps and gaps should not occur between parcels. However, existing land administration systems adopting 2D parcels have begun to lose their efficiency while coping with rights, restrictions and responsibilities (RRRs) belonging to land which become more complicated day by day. This complexity is mainly caused by overlapping and interlocking constructions appear particularly in urban areas with dense housing. The challenge is how to project these structures onto the surface to obtain $2 \mathrm{D}$ parcels in conventional cadastral systems (Stoter, 2003).

At this point, the necessity of $3 \mathrm{D}$ cadastre concept and $3 \mathrm{D}$ property data is confronted.

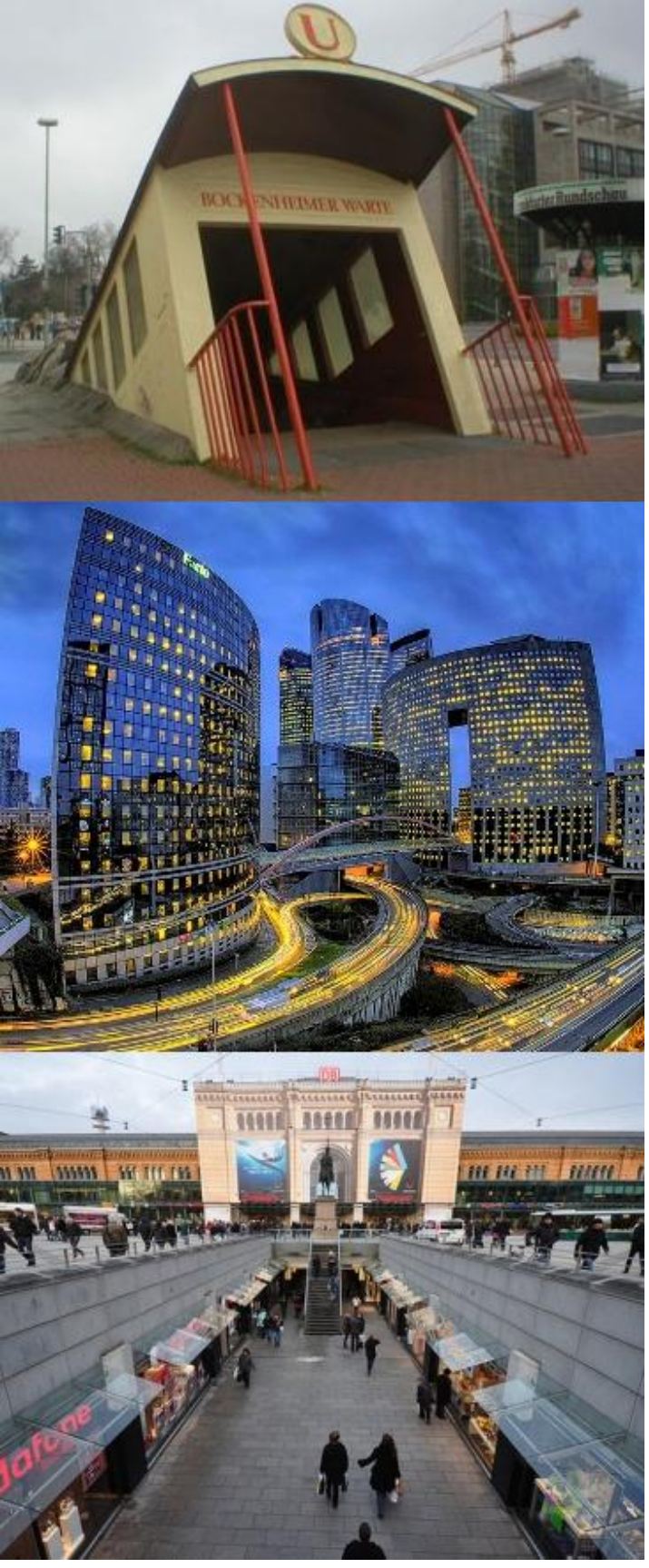

Figure 2. a) Bockenheimer Warte Station, Frankfurt b) La Defense District, Paris c) Subsurface Shopping Places at Central Station, Hannover

The requirement for a 3D cadastral system is triggered by a number of factors (Stoter, 2003):

- a considerable increase in (private) property values

- a considerable increase in the number of tunnels, cables, pipelines, underground metros, parking lots, shopping malls, buildings above roads/railways and other cases of multilevel buildings

- an upcoming 3D approach in other domains (3D GIS, 3D planning) which makes a 3D approach of cadastral registration technologically realizable. 


\section{3D CADASTRE}

A 3D cadastre is a cadastre which registers and gives insight into rights and restrictions not only on parcels but also on 3D property units (Stoter, 2003). From this point of view, conventional cadastre is required to be adapted to 3D situations for proper registration. FIG Commission 7 - Cadastre and Land Management has come up with a study namely Cadastre 2014 that might take place in 2014 in order to customize the current state of cadastral registration into an approach overcoming the deficiencies. It was an output of a four-year study and has been translated into 27 languages. It has six statements which are (Kaufmann and Steudler, 1998):

- Cadastre 2014 will show the complete legal situation of land, including public rights and restrictions!

- The separation between 'maps' and 'registers' will be abolished!

- The Cadastral mapping will be dead! Long live modeling!

- 'Paper and pencil - cadastre' will have gone!

- Cadastre 2014 will be highly privatized! Public and private sector are working closely together!

- Cadastre 2014 will be cost recovering!

The document emphasizes that the cadastral registration shall not be based on or restricted to $2 \mathrm{D}$ cadastral maps in the future. Consequently, 3D rights, restrictions and responsibilities have to be completely registered and access to legal status of multi-level property including 3D spatial information in addition to public law restrictions has to be provided (Stoter, 2003).

Moreover, title deed plans \& cadastre map sheets, which are one the primary registers, are indespensible for property law and technical cadastre applications regarding to the article 1003 of Civil Law no 4721 saying "The plan based on official measurement forms the basis for the registration and determination of an immovable property to land registry" and the article 719 saying "...Boundaries of the immovable properties are determined by the title deed plans and boundary signs on the land. Unless they match each other, the actual one is the boundary on the plan...".

When considered from this point of view, interpretation can be done using building floor space boundary to be obtained from oblique images and state of building in plan. In the case of nadir images, on the other hand, it is not possible to comment by using the display/drawing of building balcony or roof projection and state of building in plan.

At this point, the importance of 3D GIS has risen. This concept requires acquisition of $3 \mathrm{D}$ data and creation of objects, visualization and navigation in $3 \mathrm{D}$ environment and $3 \mathrm{D}$ analyzing and editing.

In recent years, oblique photogrammetry, whose applications are gradually spreading, is used as an effective method for producing 3D data.

\section{OBLIQUE PHOTOGRAMMETRY}

Oblique photogrammetry is a photogrammetric method, which combines conventional nadir images together with oblique images acquired at high angles to build 3D city models with texture data obtained from oblique images (Petrie, 2008). Single or multiple camera systems mounted on airplane, helicopter or unmanned air vehicles can be used in this approach. In addition, GPS - IMU integration is adopted as in classical aerial photogrammetry.

In the GDLRC, the project of "Oblique Camera and Environmental Components" was prepared for the purpose of establishing oblique image basis required in 3D Cadastre, Property Evaluation and Marketing studies and it was approved by the Ministry of Environment and Urbanization. The components of the project includes procurement of oblique camera and software, acquisition of $1.000 \mathrm{~km}^{2}$ oblique imagery annually, production of 3D city models and publish as WMS and integration of produced 3D city models with MEGSIS and other systems.

The advantages of oblique photogrammetry can be grouped as follows (Karbo and Schroth, 2009):

- Imaging all sides of structures and performing their accurate measurements

- Performing distance, height and slop measurements on field

- Exposing blind spots

- Determining objects that are hard to see in orthophotos such as lamp posts, telephone poles etc.

- Integrating with GIS database and visualizing GIS data in 3D.

There are many camera systems used in oblique photogrammetry. As already mentioned, approaches differ from single camera to multiple camera systems. The most preferred and effective system is accepted as the one having vertical and oblique cameras together. Track'Air Aerial Survey Systems MIDAS, Pictometry - PENTA DigiCam, Hexagon Geosystems - Leica RCD30 and Microsoft - UltraCam Osprey can be given as examples (Petrie, 2008).

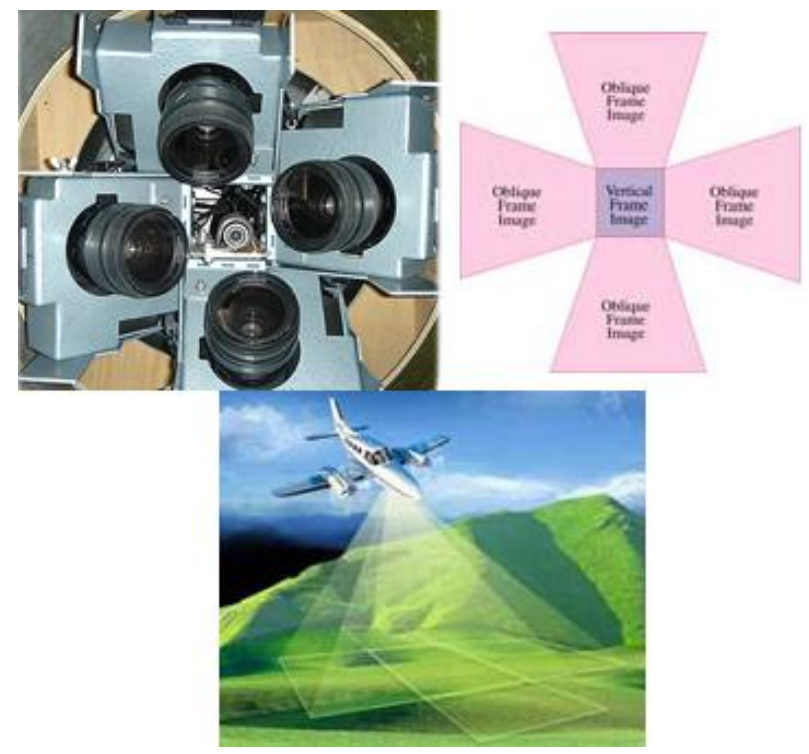

Figure 3. Five camera system (Petrie, 2008) 
In this system, oblique cameras are mounted in north, south, east and west directions with an angle of about $40^{\circ}-45^{\circ}$. The nadir camera locates in the middle. The average flying height is $1000 \mathrm{~m}$ and resolution is approximately $15 \mathrm{~cm}$ for nadir images and 12-18 cm for oblique images (Nelson, 2008).

This configuration generally provides minimum 12 and maximum 24 images of a point, which allows the establishment of image libraries by gathering images meeting the quality standards after the completion of photogrammetric processes.

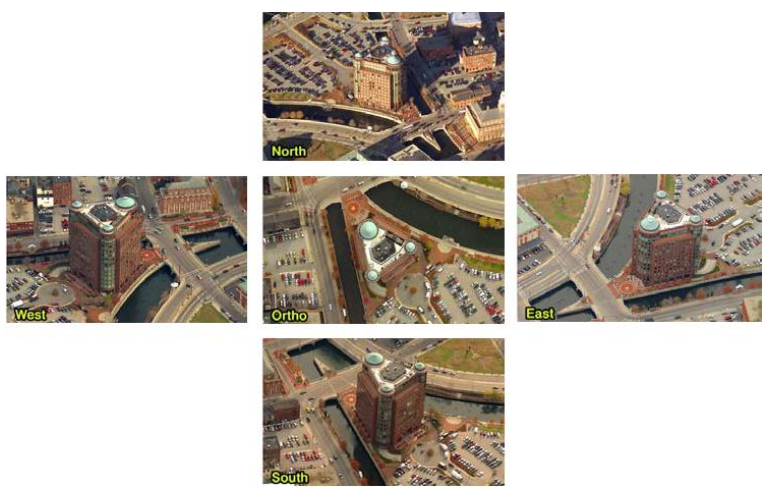

Figure 4. Five views of a building (Nelson, 2008)

\section{APPLICATIONS}

Oblique Photogrammetry is used as a powerful tool in a wide range of applications. Applications can be generally grouped into 5 main topics, which are (Grenzdörffer et al., 2008):

- Tax Assessment \& Building Deviation

- Urban and infrastructural planning

- Management of military and security operations

- Critical infrastructural protection

- Cadastral capturing and management.

Since oblique photogrammetry provides accurate measurements of distances, heights and areas, it is exploited for tax assessment effectively. Together with identification and documentation of deviations, raise in tax revenues is obtained.

Powerful measurement capabilities help users to compare buildings and structures for any kinds of planning purposes. In addition, designing pylon construction can be handled easily. Line of sight analyses have an important role at urban and infrastructure planning as well.

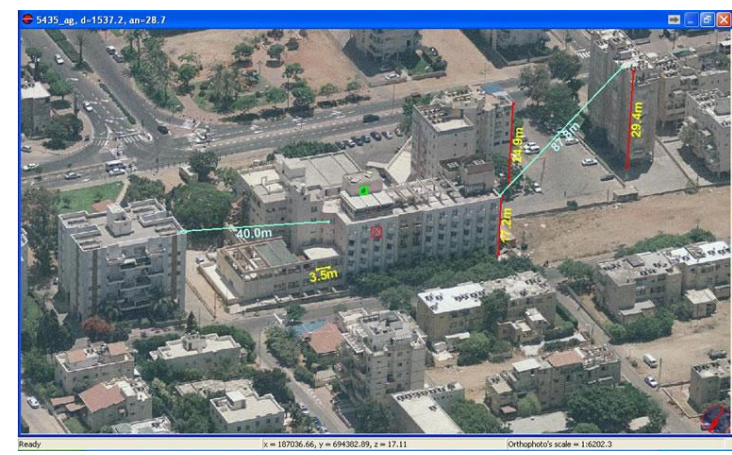

Figure 5. Height and distance measurements (Aeromap, 2006)
In terms of military and security operations, oblique photogrammetry strengthens the management by providing accurate and fast information during crisis times. This includes critical site information as well as information on surrounding areas and infrastructure. During crises, access and evacuation routes play a crucial role. Oblique photogrammetry is a great tool to do planning for them in addition to determination of entrances and openings.

Critical infrastructures including airports, harbors, terminal stations, shopping centers, power plants, water resources, military and police facilities, government buildings, hospitals, prisons, dense populated areas, tower blocks, factory premises and industrial areas can be protected using the multi-vision ability of this technology.

Oblique photogrammetry is an effective tool for cadastre projects. As mentioned several times, robust measurements on 3D space make accurate mapping and organization of cadastral activities in rural areas possible (Grenzdörffer et al., 2008). Apart from measurement capabilities, this technology might be used as a support in splitting parcels and parcel formation by preliminary boundary determination (Lemmens et al., 2007).

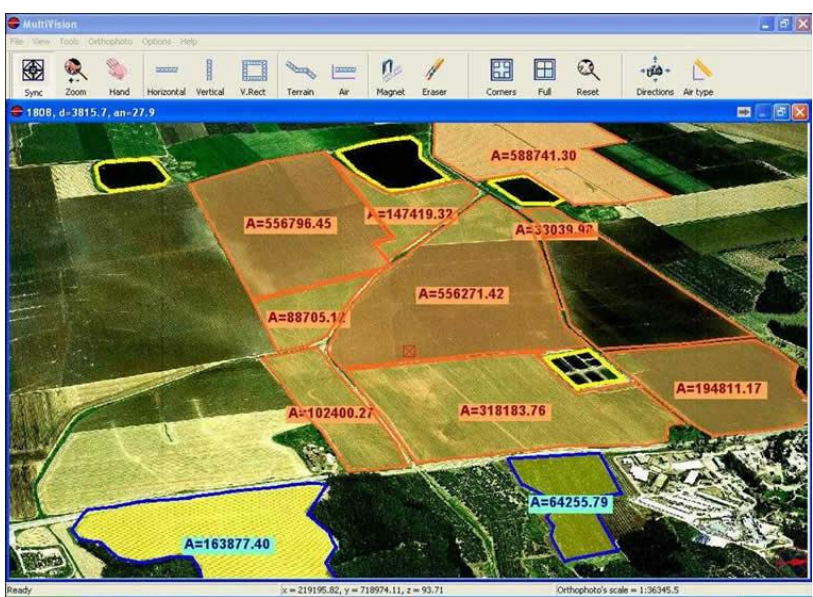

Figure 6. Parcel area measurements (Aeromap, 2006)

Realistic 3D city models obtained by texturing oblique data are used as an important base for 3D cadastre projects and provide convenience in urban planning. Besides, these $3 \mathrm{D}$ city models are used to take the environmental factors into account while performing real estate assessment.

Oblique images can be used for getting information, which cannot be obtained using topographic maps and orthophotos in the determination of land use. While it is hard to distinguish poor quality and luxury houses on vertical images, it is possible to get more meaningful data using oblique photogrammetry.

\section{CONCLUSIONS}

Intensive use of lands triggered by rapid population increase and complex city structuring enabled by technological advancements have caused existing $2 \mathrm{D}$ cadastral registration system to remain inadequate for administrating rights, restrictions and responsibilities (RRRs) belonging to land. To overcome this issue, 3D cadastre approach should be adopted and performed. Thus, healthy and effective land administration 
can be enabled, which is also the key for obtaining sustainable development.

To be able to realize 3D cadastre, 3D data is required to be gathered. Oblique photogrammetry emerges as a powerful tool to fulfill this requirement. This method can be effectively used as base for 3D Cadastre and Land Administration projects. Besides, it provides a wide range of applications not only in cadastral mapping and management but also in tax assessment \& building deviation, urban and infrastructural planning, management of military and security operations and critical infrastructural protection.

\section{REFERENCES}

$\begin{aligned} & \text { Aeromap Technology } \\ & \text { Photogrammetry }\end{aligned} \begin{array}{lr}\text { Systems, 2006, } & \text { Oblique } \\ \text { http://www.aeromapss.com/OPS-F.pdf (15 April 2013). }\end{array}$

Enemark, S., 2004, Building Land Information Policies. Proceedings of Special Forum on Building Land Information Policies in the Americas. Aguascalientes, Mexico, 26-27 October 2004.

FIG, 1995, The FIG Statement on the Cadastre. Technical Report Publication No.11, FIG Commission 7 http://www.fig.net/commission7/reports/cadastre/statement_on cadastre.html (15 April 2013).

Grenzdörffer, G.J., Guretzki, M., \& Friedlander, I., 2008, Photogrammetric Image Acquisition and Image Analysis of Oblique Images - A New Challenge for the Digital Airborne System PFIFF. In: Photogrammetric Record 2008, Nr 12/2008 pp. 372-386.

Jonas, D., 2009, How Aerial Survey in Vietnam is now Serving People and Building National Capacity. $7^{\text {th }}$ FIG Regional Conference, Hanoi, Vietnam, 19-22 October.

Karbo, N., Schroth, R., 2009, Oblique Aerial Photography: A Status Review. Photogrammetric Week 2009: pp. 119 - 125.

Kaufmann, J., \& Steudler, D., 1998, CADASTRE 2014 - A Vision for a Future Cadastral System. FIG Commission 7 http://www.fig.net/cadastre2014/translation/c2014-english.pdf (15 April 2013).

Lemmens, M., Lemmen, C., \& Wubbe, M., 2007, Pictometry: Potentials for land administration. 6th FIG Regional Conference, San José, Costa Rica 12-15 November.

Nelson, J., 2008, Lecture 7 - Photogrammetric Products. Photogrammetry Lecture Notes, KTH Royal Institute of Technology

http://www.infra.kth.se/courses/AG1322/lectures/17.pdf April 2013).

Petrie, G., 2008, Systematic Oblique Aerial Photography Using Multiple Digital Cameras. VIII International Scientific \& Technical Conference, "From Imagery to Map: Digital Photogrammetric Technologies", Porec, Croatia.
UNECE, 1996, Land administration guidelines: with special reference to countries in transition. New York and Geneva, United Nations (UN) http://www.unece.org/fileadmin/DAM/hlm/documents/Publicat Publ/land.administration.guidelines.e.pdf (15 April 2013).

Williamson, I., Enemark, S., Wallace, J., \& Rajabifard, A., 2010, Land administration for sustainable development. Redlands, California: ESRI.

Stoter, J., E., 2003, 3D Cadastre. TU Delft, PhD Thesis. 